\title{
Diligence of Directors in the Management of Corporations
}

$66 \pi$ ODERN text writers, neither English nor American, agree on the relation which the officers and directors bear either to the shareholders or the corporation itself, nor do the courts any more nearly agree than the textwriters. This is due, in great measure, to the fact that the common law rules of responsibility which would govern principal and agent, or trustee and cestui que trust, have been so modified by statute that the question has now become simply one of statutory construction, and application."1

Although it is felt that this conclusion that the relation of the directors to the stockholders and the corporation is now merely a question of statutory construction, is an extreme view of the situation, it must be admitted that legislative enactments now play a very prominent part in the final determination of such a question. Modern business conditions during the years since 1896 have brought the question of the responsibility of directors for abuses of their powers, violations of their duties, and their liability for their conduct and acts either of oinission or commission squarely before the public for serious attention. ${ }^{2}$

In that time many new statutes have been passed, old statutes have been revived, and the common law rules have been relied upon in an attempt to define clearly the duties of directors in managing the affairs of the corporation for the benefit of the stockholders and the creditors. The cases, although they have not been in accord as to the extent of liability of directors, have always deemed that there was a common law duty upon such officers of corporations. $^{8}$

An early case which recognized that liability was the case of The Charitable Corporation v. Sutton. ${ }^{4}$ There the status of a director was announced as follows:

1 (1913), 47 Am. Law Rev. 561, 563.

2 See 26 Harv. Law Rev. 467, (1913).

8 Thompson on Corporations, $\S 1265$.

4 (1742), 2 Atk. 400, 405, 26 Eng. Repr. 642. 
"I take the employment of a director to be of a mixed nature; it partakes of the nature of a public office, as it arises from the charter of the Crown.

"But it cannot be said to be an employment affecting the public government, . . . .

"Therefore committee-men are most properly agents to those who employ them in this trust and who empower them to direct and superintend the affairs of the corporation.

"In this respect they may be guilty of acts of commission or omission, of mal-feasance or non-feasance. Vide Domat's Civil Law upon this head, 2 B. Tit. 3, Sec. I \& 2."

Having recognized this duty and obligation, the courts were at once thrust into the difficult situation of defining its limits and applying it to particular cases. This article will not deal with the development of this rule in its application to acts of commission or malfeasance but the discussion will be confined to cases of omission or nonfeasance.

On this point the court in the case of The Charitable Corporation v. Sutton, supra, continued:

"To instance in non-attendance; if some persons are guilty of gross non-attendance and leave the management entirely to others, they may be guilty by this means of the breaches of trust that are committed by others.

"By accepting of a trust of this sort, a person is obliged to execute it with fidelity and reasonable diligence; and it is no excuse to say that they had no benefit from it, but that it was merely honorary; and therefore they are within the case of common trustees. Vide Coggs v. Barnard, I Salk. 26.

"Another objection has been made, that the court can make no decree upon these persons which will be just, for it is said every man's non-attendance or omission of his duty is his own default, and that each particular person must bear such a proportion as is suitable to the loss arising from his particular neglect, which makes it a case out of the power of this court.

"Now if this doctrine should prevail, it is indeed laying the axe to the root of the tree."

It is worthy of note here that this early authority referred to the director as an agent and also as a trustee. Courts have continued to do the same thing down to the present day and have never been able to say whether a director's duty should be judged by that of an agent or by that of a trustee. This is not the fault of the courts but is due in large measure to the fact that a director in some situations stands in the relation of agent to principal and in others in the relation of trustee to cestui. He has characteristics 
common to both but often stands in a position differing from either. Agents usually receive a direct consideration or compensation for their services while directors usually do not. Trustees have no interest in the subject matter of the trust while directors usually have a very substantial interest as stockholders in the property of the corporation. For this reason the problem cannot be solved by relying entirely upon analogies as the courts seem inclined to do but must be worked out upon a somewhat independent basis.

The earliest case which is recognized as a leading authority on this subject in the United States is Spering's Appeal. ${ }^{5}$ It was said in that case:

"These citations, which might be multiplied, establish, as it seems to me, that while directors are personally responsible to the stockholders for any losses resulting from fraud, embezzlement or wilful misconduct or breach of trust for their own benefit and not for the benefit of the stockholders, for gross inattention and negligence by which such fraud or misconduct has been perpetrated by agents, officers or co-directors, yet they are not liable for mistakes of judgment, even though they may be so gross as to appear to us absurd and ridiculous, provided they are honest and provided they are fairly within the scope of the powers and discretion confided to the managing body."

This statement of the rule met with a direct response in the case of Hun v. Cary. ${ }^{6}$ Referring to the above quotation that court said:

"As I understand this language, I cannot assent to it as properly defining to any extent the nature of a director's responsibility. Like a mandatary, to whom he has been likened, he is bound not only to exercise ordinary care and diligence, but ordinary skill and judgment. As he is bound to exercise ordinary skill and judgment, he cannot set up that he did not possess them . . . . One who voluntarily takes the position of director, and invites confidence in that relation, undertakes, like a mandatary, with those whom he represents or for whom he acts, that he possesses at least ordinary knowledge and skill, and that he will bring them to bear in the discharge of his duties."

In another portion of the same opinion, referring to the statement that a director is liable only for gross negligence, this same court said:

5 (1872), 71 Pa. St. 11, 24.

$6(1880), 82$ N. Y. $65,73$. 
"If gross negligence be taken according to its ordinary meaning as something nearly approaching fraud or bad faith I cannot yield to this claim; and if there are any authorities upholding the clain, I emphatically dissent froin them.

"It seems to me that it would be a monstrous proposition to hold that trustees intrusted with the inanagement of the property, interests and business of other people who divest themselves of the management and confide in them, are bound to give only slight care to the duties of their trust, and are liable only in case of gross negligence; and I have found no authority fully upholding such a proposition. It is true that authorities are found which hold that trustees are liable only for crassa negligentia, which literally means gross negligence; but that phrase has been defined to mean the absence of ordinary care and diligence adequate to the particular case."

The third case which is looked upon as a leading authority in this country is the case of Briggs v. Spaulding, decided by the Supreme Court of the United States. ${ }^{7}$ In that case the court was divided five to four. The facts showed that the directors for fourteen years prior to the failure of the bank had allowed the business to be conducted by the president. The directors were not charged with misappropriation or misapplication, or interference with any property of the bank but with the omission of duty which, if performed, would have prevented certain specific losses with which the receiver of the corporation sought to charge thein. The majority of the court decided that under the facts of the case the defendant directors were not liable.

The conclusion of the court was as follows:

. . " we hold that directors must exercise ordinary care and prudence in the administration of the affairs of a bank, and that this includes something more than officiating as figureheads. They are entitled under the law to commit the banking business, as defined, to their duly-authorized officers, but this does not absolve them from the duty of reasonable supervision, nor ought they to be permitted to be shielded from liability because of want of knowledge of wrong-doing, if that ignorance is the result of gross inattention; but in this case we do not think these defendants fairly liable for not preventing loss by putting the bank into liquidation within ninety days after they became directors . . . ."

Mr. Justice Harlan delivered a vigorous dissenting opinion on behalf of the minority of the court. In referring to the contention of the defendants that they were justified in allowing the

7 (1890), 141 U. S. 132, 165, 35 L. Ed. 662, 11 Sup. Ct. Rep. 924. 
president to conduct the affairs of the bank and in taking his word for the status of the concern, he made the following comment:

"Upon [the defendant's] theory of duty, the only need for directors of a national bank is to meet, take the required oath to administer its business diligently and honestly, turn over all its affairs to the control of some one or more of its officers, and never go near the bank again, unless they are notified to come there, or until they are informed that there is something wrong."

Referring to the degree of diligence and the extent of supervision to be exercised by the directors, the minority opinion further declared:

"It is such diligence and supervision as the situation and the nature of the business requires. Their duty is to watch over and guard the interests committed to them. In fidelity to their oaths, and to the obligations they assume, they must do all that reasonably prudent and careful men ought to do for the protection of the interests of others intrusted to their charge."

The doctrine that directors should be liable for gross negligence only does not seem to receive sympathetic support in the popular mind nor in the general declarations of the courts. They should be held responsible for the amount of diligence and care required in the particular office. This rule has been well stated by a well known text writer ${ }^{8}$ as follows:

"What constitutes a proper performance of the duties of a director is a question of fact, which must be determined in each case in view of all the circumstances; the character of the company, the condition of its business, the usual methods of managing such companies, and all other relevant facts must be taken into consideration. It is evident that no abstract reasoning can be of service in reaching a proper solution."

Confusion is added to the problem at this point by the fact that too much emphasis is usually put upon the distinction between mere ministerial acts and those acts requiring an exercise of discretion by the directors. It is true that when directors exercise their judgment concerning matters of policy they are usually not liable for resulting losses." This does not mean, however, that they may not have been careless in exercising their discretion.

8 Morawetz Corporations, $\S 552$; Camden v. Virginia Safe Deposit and Trust Co. (Va., 1913), 78 S. E. 596.

9 Excelsior W. \& M. Co. v. Pierce (1891), 90 Cal. 131, 145, 27 Pac. 69; Pollitz v. Wabash Ry. Co. (1912), 207 N. Y. 113, 100 N. E. 721; Thompson on Corporations, $\S 1270$. 
Neglect of duty by directors in discretionary as well as in ministerial acts should make them liable to those who are injured by such omissions.

There are other cases which throw sufficient light upon the rules above stated to be of value here. In the case of Swentzel v. Penn Bank ${ }^{10}$ the court pointed out that there was a popular misapprehension as to the duty of directors in administering the affairs of a corporation and continued:

"In the popular mind they are held to the rule that they ought to take the same care of the affairs of a bank that they do of their own private business."

That, undoubtedly, was the view of the court in Hun. v. Cary, supra, but is decidedly not the view in the other cases above cited. The court in Swentzel v. Penn Bank then announced what it considered to be the rule of law :

"It cannot be the rule that the director of a bank is to be held to the same ordinary care that he takes of his own affairs. $\mathrm{He}$ receives no compensation for his services. $\mathrm{He}$ is a gratuitous mandatary. A business-man generally understands the details of his own business but a bank director cannot grasp the details of a large bank without devoting all of his time to it to the utter neglect of his other affairs."

These authorities summarize the views that have prevailed and still prevail in this country as to the extent of the liability of directors. Particular courts have varied in their attitude of loose or strict application of these various doctrines. The case of Gibbons v. Anderson ${ }^{11}$ presents a state of facts where the directors of a bank absolutely neglected their duty toward the corporation, delivered over its entire management to a single director in the capacity of cashier and president, and took no trouble to familiarize themselves in any way with the business of the bank. The records of the directors showed but few entries and they were almost wholly limited to the election of directors or to the declaration of dividends. The court was clearly of the opinion that directors in this case were liable and distinguished it from Briggs v. Spaulding, supra, upon the facts of the cases:

10 (1892), 147 Pa. St. 140, 23 Atl. 405, 415.

11 (1897), 80 Fed. 345, 349. See also Dovey v. Cory, L. R. [1901] App. Cases 477; Cavanaugh v. Gould (N. Y., 1911), 147 App. Div. 281, 131 N. Y. Sup. 1059; McKinnon v. Morse (1910), 177 Fed. 576; Rankin v. Cooper (1907), 149 Fed. 1010; Warner v. Penoyer (1898), 91 Fed. 587, 33 C. C. A. 222, 44 L. R. A. 761; Yates v. Jones' National Bank (1910), 206 U. S. 158, 51 L. Ed. 1002, 27 Sup. 'Ct. Rep. 638. 
"It is the right and duty of the board to maintain a supervision of the affairs of the bank; to have a general knowledge of the manner in which its business is conducted, and of the character of that business; and to have at least such a degree of intimacy with its affairs as to know to whom and upon what security, its large lines of credit are given; and generally to know of, and give direction with regard to, the important and general affairs of the bank, of which the cashier executes the details. They are not expected to watch the routine of every day's busimess, . . . The idea is not to be tolerated that they serve as merely gilded ornaments of the institution, to enhance its attractiveness, or that their reputations should be used as a lure to customers. What the public suppose, and have the right to suppose, is that those men have been selected by reason of their high character for integrity, their sound judgment, and their capacity for conducting the affairs of the bank safely and securely."

There is another view suggested in the authorities to the effect that the directors, being stockholders, have sufficient personal interest in the affairs of a corporation to perform any duties that may devolve upon them in the course of their administration.

"It is to be remembered that they have the same interests to protect and subserve as other stockholders, and self-interest naturally prompts them to look after their own, and the degree of care they are bound to exercise is that which ordinarily prudent and diligent men would exercise under similar circumstances in respect to a like gratuitous employinent. . . . ."12

Keeping in mind ordinary business practices it is easy to realize that this view is better in theory than in application. Its principal defect is to be found in the custom of electing dummy directors so that the interests of the inajority electing them is often subserved to the detriment of the minority stockholder and of the corporation itself.

A recent writer, commenting upon the duties of an inactive corporate director, made the following remarks:

"A dogma which early prevailed (strengthened doubtless, by the circumstance that many corporations then were of the charitable type), and which has not yet disappeared, assumed that directors were rendering gratuitous service to stockholders and that accordingly there should be imposed upon the position of director as few obligations or hardships as possible, in order that men of the desired character would more readily accept election. If this idea proceeded from the

12 North Hudson Loan Assoc. v. Childs (1892), 82 Wis. 460, 52 N. W. $600,605,33$ Am. St. Rep. 57. 
supposition that it was desirable for the benefit of the stockholders or the corporation to secure as directors men of a peculiar qualification or standing, the stockholders on the other hand should be allowed to rely, in some degree at least, upon the effect of the same supposition. That reliance is frequently very real and of important consequences, but if such reliance is now to be entirely disregarded in determining the responsibility of directors, then the popular notion of the corporate director is not in harmony with the legal notion; and the only real question is whether the legal or the popular conception should prevail, whether really any desirable end is to be secured by adhering to the strict and perhaps inapplicable rules developed in the course of faltering attempts to define the position and duty of a director. It may be said that this requires the substitution of a practical or ethical standard for an existing legal standard which, however fallacious, is certain; but such substitution is the normal method by which legal rules are often developed, and if in this instance the law cannot lend itself to such development, it fails of its purpose."13

Another writer summing up his observations upon this question of the responsibility of a director in our modern corporation, asks these questions:

"Where else in human affairs may be found so admirable a combination of distinction without anxiety, of reward without toil? Would it not be well for the corporations and society at large, if penalties that are admitted to be proper in the abstract were insisted upon until the prodigious number of pseudo-directors who are now in evidence were 'squeezed out' and a really hard-working director, as distinguished from an officer, became less of an. anomaly than he seems under present conditions?"14

There is much of wisdom and warning for directors in the expression found in a recent case in Georgia. ${ }^{15}$

"Unfortunately some directors appear to think that they have fully discharged their duties by acting as figure-heads and dummies; but this is a mistake and a delusion from which some of them are now and then awakened by a judgment for damages arising from allowing the corporation to be looted while they sat by negligently and looked wise."

Perhaps the difficulty which has confronted the courts in announcing a general rule which can be applied with satisfaction to all directors would be simplified if we should abandon the ordi-

13 (1908), 8 Col. Law Rev. 18, 25.

14 i7 Yale Law Jour. $33,42$.

15 McEwen v. Kelly (1913), 140 Ga. 720, 79 S. E. 777, 779. 
nary position of looking at all directors of corporations as in the same position irrespective of the purposes or the nature of the business of the particular corporation concerned. Would it not be advisable to divide corporations into several classes for this purpose, as has been suggested, in connection with the problem of determining their implied powers? Such a classification might be as follows: (a) ordinary manufacturing, mining, or trading corporations; (b) monied corporations, as banks or insurance companies; (c) public service corporations; (d) charitable, educational, or religious corporations. ${ }^{16}$ For each class of cases we might be able to approxiinate a general rule based upon a number of decisions in each group. No abstract general rule sufficient to solve all difficulties, will ever be developed but experience in each particular line of business will soon develop a rule of conduct sufficient to protect all those interested.

It has been suggested that the easiest way of solving this difficulty is to adopt a trusteeship as a substitute for incorporation. Under that arrangement the trustee would resemble an officer and not a director and be directly responsible to the stockholders and therefore subject to fewer immunities than the present director. ${ }^{17}$

Turning now to the law on this subject in the State of California we find few cases which actually hold directors responsible for negligence and carelessness in the management of corporations. This may be accounted for in part by the fact that there seems to exist a common impression that directors are not responsible for their non-attendance upon their duties and by the further fact that those who prepare pleadings do not clearly distinguish between the various grounds of recovery against directors.

The coinmon law rule was first recognized in the case of Neall v. Hill. ${ }^{18}$ In that case the directors were charged with mismanagement, neglect of accounts, and other irregularities, which caused a depreciation in the value of the stock. In deciding the case the court held that:

"In respect to the diminution in the value of the stock it does not sufficiently appear that such diminution was caused by any mismanagement of the officers of the corporation. We

16 Canfield and Wormser Cases, p. 229; State v. Milwaukee Ry. (1912), 136 Wis. 179, 116 N. W. 900; United States v. Union Pac. Ry. Co. (1878), 98 U. S. 569,25 I. Ed. 143.

1774 Centr. Law Jour. 360; Sears "Effective Substitutes for Incorporation".

18 Neall v. Hill (1860), 16 Cal. 146. 
do not think that, under the circumstances, any loss on this account is justly chargeable in these officers. A liability of this character should only be enforced in a very clear case, and where the loss has been occasioned by gross negligence or wilful misconduct."

This was an extremely liberal statement of the rule.

In the case of Fox v. Hale \& Norcross Company, ${ }^{19}$ the Supreme Court of this state recognized a duty resting upon directors and a liability on the ground of negligence. In that case some of the directors had not participated in the inanagement of the affairs of the company but had allowed the busmess to be carried on under the direction of one member of the board. An action was brought by a stockholder to recover money paid out in extravagant prices for services and materials appertaining to the business of the corporation. These directors were not guilty of any active fraud but merely of negiligence. The court held:

"But they were not charged with negligence in the complaint, but only with fraud. Fraud and negligence, however culpable, are not the same thing. It is true that, when negligence causes an injury of the same character as would be occasioned by an intentional fraud, it is visited with the same consequences, so far as compensation to the imjured party is concerned, but the plaintiff has no right to demand a conviction of fraud when no fraud has been committed. When he relies on fraud he ought to plead fraud, and when he relies on negligence he ought to plead negligence, not only because the defendant has a right to know what the charge is which he is called upon to meet, but because the defenses are different. An action for relief on the ground of negligence is ordinarily barred by the statute in a shorter time than an action for relief on the ground of fraud."

In the case of Pacific Vinegar Works v. Smith ${ }^{20}$ the question of the duties of directors in the management of a corporation was presented in a very practical situation. The action was brought by a corporation against the estate of the deceased president to recover as damages, the balance remaining due on certain promissory notes executed by him as president of the corporation, without authority and against the express instructions of the board of directors. It was sought to charge the directors with responsibility based upon their knowledge of the facts contained in the books of account and record of the corporation. The court, speaking 
through Mr. Justice Henshaw, stated the rule as follows:

"In this, appellant contends for the rule that the officers, and particularly the directors of a corporation, are chargeable with knowledge of the facts which its books of account and record disclose. This is unquestionably the rule, a rule, as is said by Mr. Justice Brewer in First National Bank of Fort Scott v. Drake, 29 Kan. 3II, (44 Am. Rep. 646), which is 'founded in public policy, essential to the safety of third parties in their dealimgs with the bank, and to the protection of the stockholders interested in its welfare and safe management. So far as is necessary to accomplish these results, it should be carefully and strictly upheld; but it should not be carried beyond this, or to such an extent as to work injury to the bank.' The rule itself and the limitation of its application cannot be more aptly stated than in the language just quoted. It is designed to protect, and limited to the protection of, third parties and of stockholders, whose trustees and agents the directors are."

The rule could not be applied to the situation before the court since it was being urged against the corporation on behalf of a president who had been faithless to his trust and had taken advantage of his position.

In an earlier case between the same parties, ${ }^{21}$ where the corporation was seeking to enjoin the transfer of the notes above referred to but which were not then due, and in which the plaintiff Smith was also seeking to recover the amounts of the notes against the corporation, this question of the knowledge of the directors was discussed by the court. It was raised in connection with the contention made by the defendant Sunith that the board of directors had ratified his acts in dealing with the notes and that since the directors were charged with knowledge of the affairs of the corporation they had ratified the transaction by failing to object. The court, however, held that the directors under the facts of the case were not in fault. They were excused because it affirmatively appeared that knowledge of these facts was concealed from the board of directors by the secretary and by the president of the board. The directors made inquiries in open meetings about these transactions and were deceived by the affirmative answers of the secretary and by the silence of the president. The court concluded:

"Under these circumstances it cannot be successfully argued

21 Pacific Vinegar Works v. Smith (1904), 145 Cal 352, 357, 78 Pac. 550, 104 Am. St. Rep. 42. 
that the president of the corporation is entitled to invoke the doctrine of implied ratification, and thus reap the fruits of his own concealment."

In the case of Nash v. Rosesteel ${ }^{22}$ it was held that where the good faith of directors was not attacked in the transaction and no actual knowledge of an erroneous inventory nor an intent to deceive were relied upon that the directors

..." were justified in relying upon subordinates and employees for data upon which to base their corporate action in declaring the dividend, and were justified, in the absence of anything constituting gross negligence, in accepting and acting upon their reports."

The duty of a director has been clearly distinguished from the duty of an officer of a corporation, such as a manager. The leading case upon that subject in this state is San Pedro Lumber Company v. Reynolds. ${ }^{23}$ The manager of a corporation and the book-keeper were charged with neglect of duty and the abstraction of corporate funds. On appeal it was contended on behalf of the manager that

“... he was liable only for want of ordinary care in einploying the bookkeeper Drane; that Reynclds' position is like and his responsibility the same as that of a director of a corporation in his relation to the stockholders. [Cases cited] ... The duties of Reynolds as manager are not identical with the duties of a director, and the cases are not in point. Reynolds was the agent of the corporation."

Although this case does not give us a rule concerning the duties of directors, it does declare that their duties are soinewhat different from and not as strict as, the duties of their immediate employees who are entrusted with the affairs of the corporation. Where directors receive pay for their services and practically full compensation for their time they should be held for the same degree of care as a manager. ${ }^{24}$

These authorities although they do not provide us with a complete working rule, nevertheless, clearly recognize that in this state a director is liable for neglect of duty under the common law doctrine. His liability, however, is not entirely regulated by that rule but has been modified by a constitutional provision

22 (1908), 7 Cal. App. 504, 509, 94 Pac. 850. See, however, Cornell v. Seddinger (1912), $237 \mathrm{~Pa}$. 389, 85 Atl. 446.

23 (1898), 121 Cal. 74, 81, 53 Pac. 410.

24 Billings v. Shaw (1913), 209 N. Y. 265, 103 N. E. 142. 
and a number of legislative enactments. ${ }^{25}$ Some of these provisions will be referred to particularly since they associate. themselves with the question under discussion.

Article twelve, section three of the Constitution reads in part as follows:

"The directors or trustees of corporations and joint-stock associations shall be jointly and severally liable to the creditors and stockholders for all moneys embezzled or misappropriated by the officers of such corporation, or joint-stock association, during the term of office of such director or trustee."

This provision was first construed in the case of Fox v. Hale \& Norcross Coinpany, supra. The court, speaking through Chief Justice Beatty, said

"This clause of the constitution has never been construed, so far as I can discover. According to its literal terms, every director of a corporation is severally liable for the full amount of any misappropriation of its funds during his term of office, without respect to any question as to his own culpability, and the argument of counsel is that it must be enforced according to its letter,-ita lex scripta est, - and hence a director, no matter how innocent he may be, and no matter how hard the case may be, inust be adjudged to pay, at the suit of any stockholder, the whole of any misappropriation of corporate funds occurring during his term of office. And therefore, according to the contention of counsel, if some large stockholder of the Hale \& Norcross Company, with the sole purpose of protecting his own interests and the interests of the other stockholders, had, by cumulating his stock, secured an election to the board of directors, and as a member of the board, had opposed the milling of low-grade ores, or the payment of more than $\$ 4.50$ per ton for milling, and had to the utmost of his ability, guarded the interests of the company in every direction, he could, nevertheless, have been singled out by any stockholder and compelled to make good the entire loss caused by the willful and corrupt misconduct of a hostile board.

"If this construction must obtain, it seems very clear that no man with any property or character to lose will be willing to serve as director of a California corporation after it becomes known that the constitution contains such a provision. I do not think, however, that the construction contended for can be allowed. It does seem that it was the

25 Cal. Const., art. xii, § 3; Cal. Civ. Code, $\S \S 308,309$, 578, 579; Cal. Pen. Code, $\S \S 558-572$, incl. 
intention of the farmers of the constitution to make each director of a corporation severally liable, whether individually culpable or not, for certain kinds of losses to the corporation occurring during his term of office; that is to say, he is made liable for embezzlement or misappropriation of corporate funds by officers of the corporation. But in my opinion the word 'misappropriation' is to be construed by the maxim 'noscitur a sociis'. It means something like embezzlement, or, in other words, it means the misapplication of funds intrusted to an officer for a particular purpose, by devoting them to some unauthorized purpose, and does not apply to the payment of an extravagant price for services or materials properly appertaining to the business of the corporation,which is this case. For losses occasioned by such means the law affords an ample remedy, without the need of resorting to the constitution, against those who are justly responsible, whether by reason of fraud or negligence; but the law does not in such cases visit upon the innocent the sins of the guilty, and if the liability arises from negligence, the action must be commenced in two years after it accrues, whereas, if it arises out of fraud, it may be commenced at any time within three years after the discovery of the facts."

For "certain kinds of losses" then the director was to be responsible irrespective of his negligence or other culpability. Poor management and extravagant prices were not included under the term "moneys misappropriated". A few years later the court was again called upon to determine whether certain other transactions were included in that term. That was in the case of Winchester v. Howard. ${ }^{26}$ That was an action by a depositor in a savings bank brought on behalf of himself and any other creditors of the bank who might choose to join, seeking to hold the directors liable for money alleged to have been misappropriated by the defendants while they were directors of the savings bank. The particular acts complained of consisted in taking money out of the savings bank and advancing it to another bank in which the directors were interested as stockholders and taking in return for the money, the unsecured paper of the second bank. The plaintiff sought to charge the defendants under the provisions of the constitution making thein liable for moneys embezzled or misappropriated. The complaint was demurred to and the demurrer was sustained in the lower court. The Supreme Court, on appeal, reversed the decision of the lower court and overruled the

26 Winchester v. Howard (1902), 136 Cal. 432, 443, 64 Pac. 692, 89 Am. St. Rep. 153. 
demurrer. The principal question in the case was whether the facts alleged constituted a misappropriation within the provisions of the constitution. It was strongly contended that the dealings of the directors with the moneys of the savings bank did not amount to a misappropriation but were merely bad investments in unsecured paper and that, therefore, the liability was one based on negligence or fraud and not upon the constitutional provision as construed in the case of Fox v. Hale \& Norcross Company, supra. The court in deciding that the acts complained of amounted to misappropriation within the provisions of the constitution, based its conclusion upon the following grounds:

"Directors and officers of corporations, as well as trustees, have always been held responsible for loss resulting from misappropriations of the irust property made by them or with their consent. The character of the misappropriations for which the officers who made them can be held responsible to the corporation has been settled in many cases. The liability has existed ever since there have been courts of equity and corporations or trustees. The constitution does not change the nature of the liability, except that for its purpose it is limited to moneys misappropriated. No officer, omitting for the nonce the suretyship, is made liable for any act or to any greater extent than he was liable before the constitutional amendment. The constitution merely makes the directors sureties for their fellow-directors and for the officers of the corporation for moneys, when so misappropriated as to make the officer misappropriating liable, and authorizing the creditors and stockholders to sue. What such liabilities are, as I have said, are old and familiar questions, and, I repeat, it seems obvious to me that such misappropriations are those for which the directors are liable.

"Both sides rely upon some remarks made in Fox v. Hale \& Norcross Company, $108 \mathrm{Ca}$. 369. Nothing decided in that case, and no doctrine announced, is at variance with these views. The allegations of the complaint in this case clearly bring it within the rule there laid down. The misappropriations are like embezzlements, and there was a 'misappropriation of funds intrusted to an officer for a special purpose, by devoting them to some unauthorized purpose'.

"I do not contend that the directors are liable beyond that. Not that the measure is harsh, and to be limited for that reason. Nor do I appreciate the importance of the question whether the law is penal or not. It is not penal in the technical sense, as it allows no recovery as a punishment, but only to compensate for a loss. But the liability created is that of suretyship, in which the innocent always suffers for the guilty, and therefore the surety may always stand upon 
the very letter of his bond. But the language of the law is unambiguous, and the words used have well-defined meaning and have been frequently used by courts in relation to the same species of liability for centuries.

"No one contends that the suretyship extends to damages resulting from mere negligence not resulting in some misappropriation, nor to loss through bad management or incompetency or mistake, and I have no criticism to make upon the language used in Fox v. Hale \& Norcross Company, ro8 Cal. 369 , unless there is an intimation that the plain language of the law is to receive some unusual construction on the supposition that it is a harsh and unwise law. Whether the policy be good is not for us nor for the legislature. The design plainly was to prevent speculating in corporate funds by directors and to make them vigilant for their beneficiaries.

"Upon this general subject counsel for respondents states a case which he evidently thinks a difficult one. Supposing Howard had no personal interest in the alleged misappropriations, but was animated only by a desire to promote the interests of the savings bank, the question would test the matter very well. He says national banks cannot loan on real estate; savings banks, with some exceptions, can loan on no other security. If loans were made by each bank in violation of this rule, but solely in the interest of the bank, would the loan constitute a misappropriation for which the directors would be liable? If loss ensued, unquestionably the directors would in each case be liable. (Cal. Civ. Code, $\$ 2238$.)

"The rule of noscitur a sociis may be further illustrated. Section I7 of article XI of the constitution declares that the using of public money by an officer having charge of it for any purpose not authorized by law shall be a felony. Section 2I of article IV is of similar effect, and was in the former constitution. Section 424 of the Penal Code, which was in force when the present constitution was adopted, makes it a felony in an officer having the custody of public money to use the same for any purpose not authorized by law. These are examples of the misappropriation of trust funds. I think it clear that when an officer of a corporation knowingly appropriates funds intrusted to him, for unlawful and unathorized purposes, and loss ensues to the corporation, the directors are liable under this clause of the constitution."

There was a dissenting opinion in this case, a part of which was as follows:

"It is not alleged that the money was embezzled by any officer of the corporation. It is not alleged that it was used for any unlawful purposes or converted by any officer to his own use, It may be, and probably is, true that the money of the savings bank should not have been loaned without 
security, but we cannot think that a loan made by an officer of a bank, in good faith, for the bank and not for his own gain, would be a misappropriation within the meaning of the constitutional provision."

This dissenting opinion was based upon the proposition that the facts alleged in the complaint constituted maladministration in the affairs of the bank rather than a misappropriation of its funds.

The decision of the court in this case can be rested upon the fact that the money in the savings bank was indirectly used for the benefit of the defendants who were stockholders in the bank to which it was handed over. It was misappropriation approximating embezzlement and the court so states "it may well be contended that these acts constitute embezzlement under section 506 of the Penal Code." The money was used to keep alive a concern in which the defendants were interested. It was not an investment based upon a transaction with an independent third person. They were indirectly using the money for their own purposes. "While directors have great powers as directors they have no special privileges as individuals." 27

In a more recent case, ${ }^{28}$ an action was based upon allegations of misappropriation under the provision of the constitution. The directors were sought to be charged with misappropriations alleged to have been made by the president of the board. He had undertaken to sell stock to certain people, had received their money. He supplied them with treasury stock, later purchased outstanding stock and returned it to the treasury. The court held that the money taken from these persons was not money of the company "misappropriated" because the sales were merely sales by the president for future delivery made on his own account. The company was in no way responsible for them. The evidence was in conflict on many points and the court granted a non-suit as to the defendant directors.

In another case, directors of a corporation were held liable for moneys misappropriated. ${ }^{29}$ In that case money was deposited by laborers with the corporation, a general trading concern, for safe keeping. It was used by the company for its own purposes and the

27 People v. Knapp (1912), 206 N. Y. 373, 99 N. E. 841. See 5 Mich. Law Rev. 559, commenting on Peopie ex rel. Perkins v. Moss (1907), 187 N. Y. 410.80 N. E. 383.

28 Hercules Oil Co. v. Hocknell (1907), 5 Cal. App. 702, 91 Pac. 341.

29 Vujacich v. The Southern Commercial Co. (19i3), 21 Cal. App. 439, 132 Pac. 80. 
court held that the directors before the court were personally liable. The decision was based on the case of Winchester v. Howard, supra, but the constitutional provision was not discussed.

"Where the business of receiving deposits by a corporation is so general as it was with the corporation defendant herein, it must be presumed that the directors had full knowledge of the manner in which such moneys were kept or used, and unless a showing is made of some excuse, such as a protest offered by the director not consenting to the misappropriation and of steps taken by such director to prevent loss from accruing to the depositors, such director becomes personally liable to the persons damaged."

The court held that the evidence was sufficient to show that the money had been embezzled by the officers of the corporation. It was delivered for safe keeping merely and any investment ammi-mind to a misappropriation under the terms of the trust. This court announces a very strict rule of conduct for directors and practically makes them sureties for their fellow directors by presuming knowledge on their part, and this without relying upon the provisions of the constitution. When knowledge is presumed, their consent is presumed unless they take active steps to show that they do not consent.

The provision of the constitution under discussion has been held to be self executing and the proper remedy on behalf of creditors is by a bill in equity where all the creditors are parties or are represented. $^{30}$ In the case of Winchester v. Howard, supra, it was held in this connection that any creditor may institute proceedings upon this liability and if the necessary parties are not brought in and that fact is made to appear, the court should order them to be brought in.

After the decision in the case of Winchester v. Howard, supra, a compromise was made wherein one of the defendants paid to the plaintiffs a certain sum of money. Subsequent to that time one of the creditors of the corporation who had not joined in the suit petitioned for a share of the amount received by the other creditors by way of compromise. It was held that he could recover no portion of that amount. ${ }^{32}$ The liability of directors under this constitutional provision is not penal but is contractual and does not

30 Winchester v. Mabury (1898), 122 Cal. 522, 55 Pac. 393.

31 Niccolls v. Rice (1905), 147 Cal. 633, 82 Pac. 321. 
terminate on the death of the director but survives against his estate. $^{32}$

Referring to the principal provisions of the Civil Code on this subject it is apparent that they were not drafted for the purpose of making more definite the duty of a director to use care and diligence in the management of the affairs of a corporation. Section three hundred and eight in this connection merely provides "They must perform the duties enjoined on them by law and the by-laws of the corporation." Section three hundred and nine merely prohibits them from making dividends except from the surplus profits of the business and from creating debts beyond their subscribed capital stock and from dividing, withdrawing, or paying to stockholders any part of the capital stock and from changing the amount of capital stock excepting as provided in the statute. This section does provide, however, that directors who enter their dissent on the minutes at the time shall not be liable for any of those acts, also, that they shall not be liable if they are absent from meetings when those acts happen. This latter provision does not tend to enhance the responsibility of directors in this matter because they may excuse themselves from responsibility by mere non-attendance which, as a matter of fact, is a common kind of negligence on their part.

Section five hundred and seventy-eight of the same code does not offer any substantial protection to corporations or persons interested therein. That section is concerned with savings and loan corporations and provides that where any director or officer shall borrow any of the deposits or funds of such corporation, his office shall thereupon become vacant. This provision can only be availed of at the instance of the state..$^{33}$ A more complete and detailed basis of liability than the one found in the Civil Code has been worked out in the Penal Code of this state. ${ }^{34}$ Section five hundred and sixty-eight of that code provides

"Every director of a corporation or joint-stock association is deemed to possess such a knowledge of the affairs of his corporation as to enable him to determine whether any act, proceeding, or omission of its directors is a violation of this chapter."

Section five hundred and sixty-nine of the same code provides in

32 Major v. Walker (1913), 23 Cal. App. 465.

33 Brittan v. Oakland Bank of Savings (1899), 124 Cal. 282, 57 Pac. 84, 71 Am. St. Rep. 58.

$34 \S 558$ to 572 , incl. 
part that every director who is present at a meeting where any act in violation of a provision of the Penal Code occurs is deemed to have concurred therein unless he enters his dissent upon the minutes. Instead of excusing a director from liability on account of absence from a meeting as is done in section three hundred and nine of the Civil Code, section five hundred and seventy of the Penal Code provides that

"Every director of a corporation or joint-stock association, although not present at a meeting of the directors at which any act, proceeding, or omission of such directors, in violation of this chapter occurs, is deemed to have concurred therein, if the facts constituting such violation appear on the records or minutes of the proceedings of the board of directors, and he remains a director of the same company for six months thereafter and does not within that time cause, or in writing require his dissent from such illegality to be entered in the minutes of the directors."

For the healthy development of corporations and their business relations in general, more emphasis should be put upon the civil liability of directors than upon their penal liability. Many penal statutes have been passed because civil relief has been found inadequate. In this state conditions could be materially remedied by putting into the Civil Code provisions resembling the sections of the Penal Code above cited.

It is undoubtedly true that the courts are striving to fix definitely the responsibility of directors. Legislation can be of assistance, but before it can be effective business conditions must be analysed and corporations must be classified according to the nature of their business. The rule that directors must exercise "the same degree of care and prudence that men prompted by self-interest generally exercise in their own affairs", ${ }^{35}$ might be the only rule for the directors of some corporations and be extremely harsh for others.

Business reorganization may be capable of developing directors of different classes, those directly charged with the management of the business, quasi managers, and those standing in an advisory capacity merely. Heretofore men have felt justified in undertaking more directorships than they could possibly understand or give their attention to. The consequence is that the investing public, stockholders and creditors, have often lost their money

${ }^{35}$ Hun v. Cary (1880), 82 N. Y. 65. 
and have not been reimbursed. The attitude of the public toward corporate directors seems to be this:

"Can anybody bring them to account? It is next to impossible to do so. If you undertake it you will find it a game of hide and seek, with the objects of your search taking refuge now behind the tree of their individual personality now behind that of their corporate irresponsibility". ${ }^{36}$

This attitude is justified in large measure by past experiences but it fails to take into account the efforts of the courts of the present day to answer the demands of the investing public. Investigation of the recent decisions of the courts will show that they are entirely sympathetic with those demands. Before this problem can be satisfactorily solved the courts must be assisted with some well considered legislation and busmess reorganization.

Berkeley, California.

M. C. Lynch.

s6 Woodrow Wilson, "The New Freedom". 